\title{
Effect of Customer Perception on Salesperson Owned Commitment in Customer-Salesperson Relationship
}

\author{
Omidreza Ghanadiof, Ali Sanayei, and Mahdi Emami
}

\section{ABSTRACT}

Selling products and gaining profit is the main mission of a private Sales forces with their specialized relationships can determine the fate of transactions and make companies successful in achieving their ideal goals. Buyer-seller relationships can significantly reduce the marketing costs of the organization. Therefore, the impact of sales forces in an organization is relatively high in the past. A better understanding of the sales professional dimension will lead to the formation of long-term relationships and increase a company's profitability. However, although much research has been done on the issue of company-customer relationships, there have been extensive studies on the perception of consumer behavior by vendors. Therefore, the aim of this study was to investigate the effect of trust, reputation, and reputation of the seller on the commitment to the seller with the mediating roles of good interaction and perceived risk. The statistical population of this study was 250 customers of a retail company. In order to collect the required data, an electronic questionnaire was designed and distributed among the statistical reporters using the available sampling method. Validity of the questionnaire using content and structural methods was determined.

Keywords: buyer-seller, consumer behavior, CRM, customer perception.

\author{
Submitted : June **, 2021 \\ Published : July 23, 2021 \\ ISSN: 2507-1076 \\ DOI: $10.24018 /$ ejbmr.2021.6.4.964 \\ Omidreza Ghanadiof \\ Graduated of Industrial Management, \\ School of Technology, University of \\ Central Missouri, USA. \\ (e-mail: omidof90@ gmail.com) \\ Prof. Ali Sanayei \\ Department of Business Management, \\ Faculty of Administrative and Economics, \\ University of Isfahan, Isfahan, Iran. \\ (e-mail:_a_sanayei@ase.ui.ac.ir) \\ Mahdi Emami \\ Master of Marketing Management, \\ Department of Management, Faculty of \\ Administrative Sciences and Economics, \\ University of Isfahan, Iran. \\ (e-mail: m.emami@ ase.ui.ac.ir) \\ *Corresponding Author
}

\section{INTRODUCTION}

Selling products and gaining profit is the main mission of a private organization and having a perfect sales team has a great role to protect the relations with customers. One of the main challenges might be the selling process. Unfortunately, most companies have believed that selling is a not process. As a matter of fact, the selling process is the last stage of marketing in the relationship to customers. Ignoring this fact might has some consequences for them. Customer perception of the seller in terms of expertise, credibility, and reputation of the seller plays an important role in establishing a strong and long-term business relationship. In this study, we review and evaluate variables and their impact on the perception of the customers in the sales process.

\section{THEORICAL RESOURCES}

Trust is a credit that is gained from the ability based on experience and others' knowledge to do a special task. In sale literature trust means good faith in a relation that a seller does and aims to gain interactive benefits and avoid opportunistic situations [3]. [16] found trust as a prerequisite to create and protect long-term relations between customer and seller believes that a customer will deposit his/her fund to the seller where trust him/her. Considering that, credit causes improvement in the customer persuading process in purchase interactions so service companies or their sellers that are trusted by customers can affect customer purchase decisions [15]. Expertise means seller special knowledge that proves his/her merit by his/her competence and ability to answer satisfyingly to special questions in interactions [13]. Research that has done by [21] shows sellers' low perception of customers. They said that if sellers would be better trained or collect accurate information, can improve sale units' efficiency. Customer-oriented salespeople as well as consulting salespeople who are responsible for building and maintaining long-term customer relationships need to have a greater understanding of the goals, strategies, and practices relevant to customers [22]. Also, [19] studies shows that consult-based sale training increases sellers' ability to present better values in comparison with competitor's value. Continuously presentation increases satisfaction and buyer's fidelity and decreases sensitivity to price by buyers. Increasing the chance of customer protection by decreasing the cost of customer replacing exactly brings more benefit for the company in comparison to catch new customers that improve the amount of sale unit profit [18]. In sale literature seller appearance is defined as good faith truthfulness and seller attention to the customer [9]. If the seller would be reliable customer can trust him/her about his expert knowledge to solve the problems [1]. In the other hand studies about appearance show that when a credible person has been chosen, the presented information would be more cogent and there is more probability to tempt purchase purpose and 
chosen trade brand. [13] for success the sellers should persuade customers to buy products, so seller appearance is one of most important factors to encourage customer to buy. The credit is described as a source that recipient gain the trust, merit, and jurisdiction for it. If the buyer had higher perception of seller appearance compared to others, the customer would better comprehend the seller messages [21] [7] found joyful interaction as an emotional and cognitive evaluation that is gained from interpersonal relationship and shows powerful connection with each other based on some links. Enjoyment defines as emotion as an answer to external motive question and relate that to human information evaluation processes [6].

Satisfaction is an emotional research of percept assessment between past expectation and real experiments. Satisfaction divides to two general groups 1-satisfaction comes from an especial deal and 2-general satisfaction. In the opposite of satisfaction assessment that comes from an especial deal, customer general satisfaction shows the overall imagination of past deal experiments with sellers and researchers suppose that pleasant interaction in person mental assessment of emotional factors. Lin and $\mathrm{Wu}$ [14] understood risk in sale literature comes when customers relate the emotional result from uncertainty and negative potential consequences to a relation that doesn't come from urgent perspective profits for purchasing and relate to potential consequences that a buyer engages to with seller. In every risk there is amount of uncertainty and probability. So, there is a direct connection to make decision and organize in future. Of course, every risk is believed as opportunity for other group, and this relate to risk and human conceptions. As security depends on perception and mentality, risk also depends on human perception. Chang and Tseng [5] customer tendency to protect long-term relation with a person comes from positive emotional about relation quality between buyer and seller [8] commitment to seller is a deep relation based on products repetitive purchase or chosen services that happens continuously in future, despite conditions and competitors. Marketing attempts to prevent negative behaviors in present customers [4] according to these cases and article goal is based on studying trust effect. Expertise and seller appearance effect on customer commitment to seller by mediator roles, pleasant interaction, and perceived risk. These hypothesis and research model in Fig. 1 have shown.

1. Trust effects on mediator role of pleasant interaction.

2. Seller appearance effects on mediator role of pleasant interaction.

3. Seller expertise effects on mediator role of pleasant interaction.

4. Trust effects on mediator role of perceived risk.

5. Seller expertise effects on mediator role of percept risk.

6. Seller appearance effects on mediator role of percept risk.

7. Mediator role of pleasant interaction effects on commitment to seller.

8. The mediator role of percept risk effects on commitment to seller.

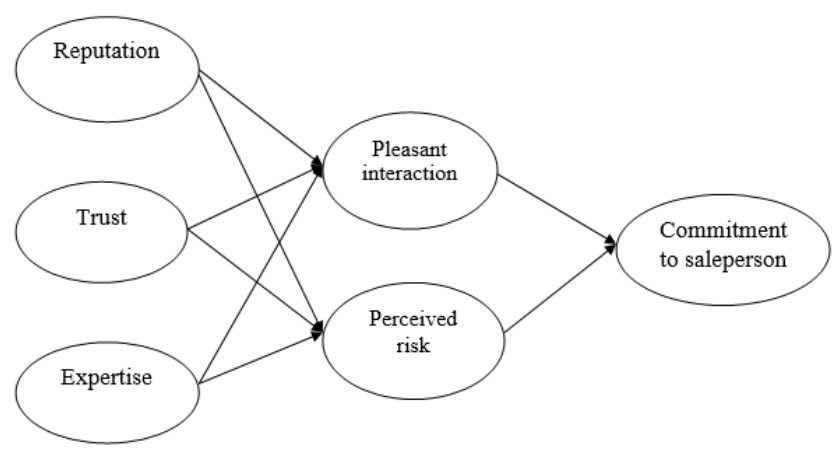

Fig. I. Conceptual model of research

\section{RESEARCH ANTECEDENT}

Arditto, Cambra -Fierro, Fuentes- Blasé, Jarabab Ana [2] in a research named "The customer conception of sellers, How can effect on their relations?" shows a model for use to customer experiments that how customer assessment of (seller-buyer interaction)effects on relations creation and development from the sight of pleasant interaction and risk. One of the main characteristics of sale power is the level of expertise and trust attraction. This research emphasizes on seller's deep knowledge about products, and they should be able to attract customer trust by protect their long-term profits. This research results show a positive and direct relation between the level of expertise and trust in order to fidelity and build a commitment to seller. Poon, Albaum and Yin [19] in a research named (studying on dangers, other benefits of interpersonal trust in buyer-seller relations in direct sale in a nonwestern country) has analyzed factors like build trust in relation between buyer and seller in direct sale and their findings show that sale managers should emphasize on the importance of customers trust attraction. Sellers' training period time and the research results show that trust dimensions may be good predictor for customers purchase intentions in a direct sale situation. In this research it is observable that all trust dimensions do not affect repetitive purchase intention for a product in direct sale positively. This problem can be explained as a negative picture of a direct sale can sometimes prevent trust dimensions effects.

[9] in a research named "The relation between sale appearances and customer behavior: the role of experimented added value by sale staff" is focused on analyze this problem that how sellers transfer the company value. This research has shown a useful knowledge to understand the source of experimental added value by seller and how this value has effect on customers behavior tendency. [12] The results show that seller appearances are a good source for customer perception of seller experimental added value and this value led to increase in customer fidelity. So, till a seller show an emotional meaningful behavior, customer will feel in a pleasant interaction and there is a will to keep on the relationship. This research shows that the pleasant interaction effects on customer fidelity and commitment to sellers positively. [18] and [17] show in a research named (The different behaviors interpersonal and advisory relations effect on buyer perceptions of seller about trust, expertise, and fidelity) results in effect of a seller interpersonal behaviors on the perception of buyer and shows that a seller interpersonal behavior effects on the buyer trust and fidelity. The results 
show that seller should pay more attention to develop interpersonal relations to help them build better reputations, deeper relations and communicate more by customers [10]. Also, the results show that the seller advisory behaviors effect on customer perception, seller expertise, and buyer fidelity considerably. There for a seller should gain the best skills and expertise to determine and analyze buyer needs and develop crateful solutions to solve these problems.

\section{METHODOLOGY}

This research is applied in goal, and in way is descriptive and has geodesic to collect information's and data. This research is based on fieldwork and has used questionnaire between customers. This research statics community has 250 members in an Iranian retailer company. The way of sampling in this research is non adventitious and the people who are more accessible had been asked. The way of data gathering in this research is divided to library method and field work method. To gather the data which belongs to research literature theory compilation and research model, recognizing the factors has done by library method like books, magazines, thesis, and internet data-basis and to confirm and verify factors collecting relative data and examine theory has used geodesic method like interview and questionnaire.

This research questionnaire contains 3 questions that are used in theory examination and studying in research model. The applied questionnaire in this research is based on theatrical basis and is similar to researches and the validity and stability is verified the measured validity in this research has studied in 3 ways: 1 - pictural validity, 2 - convergent validity and 3 - divergent validity. The picture validity shows that how similar are test questions to the topic that are used to measure the expert's ideas had been used to measure picture validity. Convergent validity shows that the criteria's which should relate with each other are related in real too. And divergent validity has proved the unity of an instrument measurement. To measure the stability in this research the internal compatibility method is used. This method is an estimation of correlation between variables that build the subjected structure. The common criteria to assess the stability in this research are Cronbach's Alpha coefficient. The gained Alpha coefficient in this research is 0.84 . This is a proper stability. For questionnaire correlation analyze method is used to find the relation between variables and measure the intensity of relation that Pierson correlation coefficient is used considering the data. The main model of this research has examined by structural questions modeling. Considering the volume of sample data analyze process and the least sensitivity compared to sample volume, using smart PLS method to modeling structural equations is used [4].

TABLE I: RESEARCH VARIABLES STABILITY TEST RESULTS

\begin{tabular}{cc}
\hline Cronbach's alpha value & Variable \\
\hline 0.841 & Trust \\
0.928 & expertise \\
0.897 & reputation \\
0.867 & pleasant interaction \\
0.866 & perceived risk \\
0.847 & Commitment to seller \\
0.84 & Total \\
\hline
\end{tabular}

\section{RESEARCH FINDINGS}

The results of Pierson correlation test for research variables is shown in Table II by studying the amount of correlation between each two variables the Zero hypothesis that is based on meaningless correlation between variables and One hypothesis that is based on meaningful correlation between each two variables by comparison the level of meaning related to correlation coefficient each two variables if it would be less than 0.05 shows the correlation between variables and verify the one hypothesis. Negative correlation coefficient between two variables shows the reversed relation between them. As is shown in Table II all variables are in relation with each other and the correlation intensity is very high.

TABLE II: CORRELATION BETWEEN RESEARCH VARIABLES

\begin{tabular}{ccc}
\hline Variable & PEARSON & $\begin{array}{c}\text { Significance } \\
\text { level }\end{array}$ \\
\hline $\begin{array}{c}\text { Trust x pleasant interaction } \\
\text { Vendor reputation X Perceived } \\
\text { risk }\end{array}$ & 0.0763 & 0 \\
$\begin{array}{c}\text { Vendor reputation X Pleasant } \\
\text { interaction }\end{array}$ & -0.641 & 0 \\
$\begin{array}{c}\text { Vendor expertise X Pleasant } \\
\text { interaction }\end{array}$ & 0.807 & 0 \\
$\begin{array}{c}\text { Trust X Perceived risk } \\
\text { Expertise X Perceived risk } \\
\text { Pleasant interaction X }\end{array}$ & -0.0754 & 0 \\
$\begin{array}{c}\text { Commitment to the seller } \\
\text { Perceived risk X Commitment } \\
\text { to the seller }\end{array}$ & -0751 & 0 \\
\hline
\end{tabular}

The research has tested the hypothesis and relations between variables by modeling structural questions with (Smart PLS software) studying the model fitting has down in 3 parts consist of measuring models fitting, structural models fitting, and overall model fitting has done. Measuring model fitting consists of three parts. Criteria stability, convergent validity, and divergent validity. In fitting study, the criteria stability has studied in three fields; factor loads comparison, Cronbach's Alpha, and compound stability. Factor load determines the balance of relation between two manifest and hidden variables. Factor loads are shown by computing the correlation of the structure criteria's and if this amount would be higher or equal to 0.4 shows the acceptable stability of measuring model and means variance between structure and its criteria is higher than the variance of that structure measuring error. The amount of Cronbach's Alpha is acceptable just in case that is used to compute measuring instruments internal accordance and would be higher than 0.7. According to the results of Table III all variables are stable in all stability measuring criterions.

\begin{tabular}{cccc}
\multicolumn{4}{c}{ TABLE III: THE RESUlTS OF CRITERIA STABILITY } \\
\hline Variables & Factor load & $\begin{array}{c}\text { Cronbach's } \\
\text { alpha }\end{array}$ & $\begin{array}{c}\text { Combined } \\
\text { reliability }\end{array}$ \\
\hline trust & 0.086 & 0.841 & 0.802 \\
Expertise & 0.91 & 0.928 & 0.979 \\
Vendor reputation & 0.94 & 0.897 & 0.898 \\
Pleasant interaction & 0.89 & 0.867 & 0.911 \\
Perceived risk & 0.95 & 0.866 & 0.856 \\
Commitment to the & 0.84 & 0.847 & 0.846 \\
seller & & &
\end{tabular}


In convergent validity, the medium of extracted variance (AVE) has shown the correlation of a structure to the criteria's if (AVE) would be higher than 0.5, then the convergent validity is acceptable. divergent validity is acceptable just when AVE for each structure would be higher than in common variance (ASV) between that structure the amount of infrastructural correlation coefficient square (ASV) in model [11] according to table number four every variable is valid.

\begin{tabular}{ccc}
\multicolumn{3}{c}{ TABLE IV: INDEX VALIDITY RESULTS } \\
\hline Variables & Convergent validity & $\begin{array}{c}\text { Divergent } \\
\text { validity }\end{array}$ \\
\hline trust & 0.722 & 0.924 \\
Expertise & 0.895 & 0.961 \\
Vendor reputation & 0.941 & 0.958 \\
Pleasant interaction & 0.823 & 0.933 \\
Perceived risk & 0.801 & 0.925 \\
Commitment to the seller & 0.825 & 0.943 \\
\hline
\end{tabular}

To assess structural model fitting, three criteria's have been studied. meaningful numbers or $(\mathrm{t})$ coefficient, determination coefficient $\left(R^{\prime} 2\right)$ and the quality criteria of structural model or excess criteria( $\left.Q^{\prime} 2\right)$. If the amount of $(t)$ virtuality would be higher than 1.96 shows the relation authentication between structures and so confirms the research thesis in all trust levels. by studying the amount of determination coefficient: 0.19 shows weak, 0.33 shows middle and 0.67 shows strong. That show the fitting strength model structural part by determination coefficient level by level. excess criteria or level of strength of inbred structures is divided to three groups 0.2 weak, 0.15 middle and 0.35 strong. GOF criteria belongs to overall part of structural equations models, there for by these criteria we can control overall fitting after structural and measuring parts fitting. $0.01,0.25$, and 0.36 are shown as weak, middle and strong amounts for (GOF)and the more GOF shows the better level of overall fitting of that model [23] as this criterion gained amount 0.756 shows the high strength of this research model. According to the results of Table V structural model fitting and overall model has done in high level.

TABLE V: STRUCTURE MODEL

\begin{tabular}{cccc}
\multicolumn{4}{c}{ TABLE V: STRUCTURE MODEL } \\
\hline Variables & $\begin{array}{c}\text { The coefficient } \\
\text { of determination }\end{array}$ & Quality Index & GOF \\
\hline trust & - & - & \\
Expertise & - & - & \\
Vendor reputation & - & - & 0.756 \\
Pleasant interaction & 0.896 & 0.732 & \\
Perceived risk & 0.532 & 0.463 & \\
Commitment to the & 0.861 & 0.789 & \\
seller & & & \\
\hline
\end{tabular}

After ensuring of fitting strength, the research theories model has been studied. according to the results in table VI, for hypothesis virtuality(meaning) test each two criteria:

1 - path coefficient,

2 - virtuality coefficient.

Has been used. Considering model path virtuality coefficient have studied the research hypothesis virtuality and if the amount of path numbers would be higher than 1.96 shows the relation authentication between structures and then research hypothesis would be verified in trust level of $95 \%$. Path coefficient or $\beta$ coefficient shows the determination amount between two hidden variables that its amount is shown between two hidden variables path on software output. In other words, path coefficient explains over-line relations, intensity, and direction of this relation between two hidden variables. The $\beta$ coefficient is between is between -1 and +1 If it is zero shows the line relation absence between two hidden variables. The results of studying on research hypothesis are shown in Table VI.

TABLE VI: PATH COEFFICIENTS AND SIGNIFICANCE

\begin{tabular}{|c|c|c|c|}
\hline Hypothesis & $\begin{array}{c}\text { Path } \\
\text { coefficient }\end{array}$ & Coefficient $\mathrm{t}$ & $\begin{array}{c}\text { Final test } \\
\text { result }\end{array}$ \\
\hline $\begin{array}{l}\text { 1. Trust affects the } \\
\text { mediating role of } \\
\text { pleasant interaction. }\end{array}$ & 0.257 & 3.245 & Approved \\
\hline $\begin{array}{l}\text { 2. The reputation of } \\
\text { the seller affects the } \\
\text { mediating role of } \\
\text { pleasant interaction. } \\
\text { 3. The seller's }\end{array}$ & 0.239 & 4.098 & Approved \\
\hline $\begin{array}{l}\text { expertise affects the } \\
\text { mediating role of } \\
\text { pleasant interaction. }\end{array}$ & 0.511 & 7.498 & Approved \\
\hline $\begin{array}{l}\text { 4. Trust affects the } \\
\text { mediating role of } \\
\text { perceived risk. } \\
5 . \text { The seller's }\end{array}$ & -0.487 & 3.48 & Approved \\
\hline $\begin{array}{l}\text { expertise affects the } \\
\text { mediating role of } \\
\text { perceived risk. }\end{array}$ & -0.261 & 1.345 & Rejected \\
\hline $\begin{array}{l}\text { 6. The seller's face } \\
\text { affects the mediating } \\
\text { role of perceived risk. }\end{array}$ & -0.125 & 1.489 & Rejected \\
\hline $\begin{array}{l}\text { 7. The mediating role } \\
\text { of pleasant interaction } \\
\text { affects the } \\
\text { commitment to the } \\
\text { seller. }\end{array}$ & 0.899 & 22.254 & Approved \\
\hline $\begin{array}{l}\text { 8. The mediating role } \\
\text { of perceived risk } \\
\text { affects the } \\
\text { commitment to the } \\
\text { seller. }\end{array}$ & -0.128 & 3.098 & Approved \\
\hline
\end{tabular}

There for according to the results came from Table VI, the conclusion shows that the trust effects on the mediator role of pleasant interaction (hypothesis number one) the seller appearance effects on mediator role of pleasant interaction (hypothesis number 2) seller expertise effects on the mediator role of pleasant interaction (hypothesis number 3) and the mediator role of pleasant interaction effects on commitment to seller (hypothesis number 7) have meaningful and positive relation. trust effects on mediator role of perceived risk (hypothesis number 4) the mediator role of perceived risk effects on commitment to seller (hypothesis number 8) have meaningful and negative relation. seller expertise effects on mediator role of perceived risk (hypothesis number 5) and seller appearance effects on mediator role of perceived risk (hypothesis number 6) have not meaningful relation.

\section{RESULTS AND SUGGESTIONS}

This research aims to recognize, distinguish, and model the trust impression, expertise, and seller appearance on commitment to seller by pleasant interaction mediator role and perceived risk. In this part of research, the results of data studying, and hypothesis and structural questions analysis will be shown separately. This research results show that trust effects on pleasant interaction positively and there is a meaningful relation. The confirmation of hypothesis number 
1 is parallel to the research results [18] this research implies that trust effects on customers assessment of interaction by sellers directly and effectively. They conclude that a seller relational behaviors effects on buyer perception considerably.

In Noll and his colleagues research a collection of seller relational behaviors named pleasant interaction is noticed and sellers' special behaviors has been noticed as mediator variable. There for these cases have been suggested:

1. Structure modification in human resource field to employ and apply sellers among people who can attract people trust better is more powerful and to do this there is different psychology tests.

2. Build a suitable system to get ideas customer suggestions, in order to assess seller trust attraction by scientific methods.

3. Build observation systems in order to assess seller performance by this industry inspect.

4. Seller interpersonal relation skill development in order to build deeper and personal relations.

The results of this research show that seller appearance effects on pleasant interaction mediator role positively and meaningful. The confirmation of hypothesis number 2 is parallel to studying research results [9].

[9] Assigns the appearance to sellers in this research and shows its importance to value creation process and seller success. There for if customers assess the seller appearance positively probably will assess the seller services too. in [9] research, the relation between pleasant interaction and seller appearance in seller final confirmation space will be done. In order to build long-term relations with seller these cases have role. So, these cases are suggested:

1. Considering the seller appearance impression on customer purchase intention sellers can increase customers intentions by confide and consult them.

2. Recognizing special characteristics to empower the sellers and compiled trainings in order to gain competition advantages in nowadays business environment.

3. Pleasant attitude to sellers so that has main role in customers purchase intention there for long-term relations with customers should develop.

This research results shows that the seller expertise effects on pleasant interaction mediator role meaningful and positively. Confirmation of hypothesis number3 is parallel to research studying. [18] they found the positive and meaningful effect of interpersonal and consultative relations on buyer perception of seller and his/her expertise. In Noll and his colleagues research the trust has mediator role among expertise and loyal relation so these cases are suggested:

1. Seller should take attention to develop interpersonal relations skills so that help them to build deep relations with buyers.

2. A seller consultative behavior effects on customer perception of seller expertise considerably.

3. A seller should gain required skills to determine and analyze buyer needs and develop creative solutions to solve the problems.

4. Apply useful things in order to increase relation quality and repeat trainings on suitable times.

The research results show that trust effects on understood risk mediator role meaningful and negatively. The confirmation number 4 with research result [2] is parallel. In this research by studying the customers perception of sellers, found that the trust effects on perceived risk mediator role meaningful and negatively. This present research results are parallel to Poon and his colleagues research results. They found that the negative picture of seller sometimes can prevent trust dimensions effects, it is found by studying the dangers and benefits of interpersonal trust advantages in direct sale, so these cases are suggested:

1. Personificated consultation and customer's control.

2. The importance of sellers focuses on high level of social and economic satisfaction protection in relations with buyers.

3. Adding value to relation with buyers.

This research results show that seller expertise effects on mediator role of perceived risk meaninglessly.

Disapprobation of hypothesis number five is similar to this research result [2]. By studying the relation between expertise and perceived risk their relation confirms by trust indirectly and means that the sellers' expertise doesn't help perceived risk decrease for under test buyers and should empower personal credit. Therefore, these cases are suggested:

1. The companies should employ sellers who are skillful to communicate with others and are intelligent enough, having high level EQ.

2. Add value to relations by high level of expertise that led to long-term relations with customers.

This research results show that seller appearance does not affect mediator role of percept risk. confirmation hypothesis number six is parallel to research result [20].

They found the interpersonal trust advantages that are a part of seller credit and appearance by studying perceived risk from buyer side, in buyer and seller relations in direct sale and finally result that the negative picture of seller can prevent trust effects sometimes. But all trust aspects do not affect repurchasing for a product directly. in Poon research trust variable and its aspects are a part of seller appearance and credit. Therefore, these cases are suggested:

1. Sale manager should encourage the staff so that they engage themselves in duties and tasks and are motivated to interact better and reduce relation risk with customers.

2. Sellers should be empowered in listening intelligently to customers to reduce relation risk among them.

3 . We suggest managers that have ceremonies and festivals in applied professional ethics that improve and increase service level to customers.

This research results show that pleasant interaction mediator role effects on commitment to seller positively and meaningfully. The confirmation of hypothesis number 7 is parallel to the results of this research [2] this research implies that the seller should know the products deeply and try to attract customers trust by protect their long-term benefits, Arditto and his colleagues research shows a direct and positive relation among the level of expertise and trust to commitment to seller.

In this research the effect of pleasant interaction on commitment and commitment to seller has been studied as two related variables coeval. there for these cases are suggested:

1. Apply the relation with customer management in order to create value and encourage customers to have relations with sellers. 
2. Attention to EQ effects on sale conformity and customers guide, listening to them and attention to their problems.

3. Ability development and sellers answering to customer needs, take attention to customers body languages.

This research results show that perceived risk mediator role effects meaningfully and positively on commitment to seller. the confirmation of hypothesis number 8 with [9] research result is parallel. [9] studies consider the effect of perceived risk on relation factors and show that there is a reverse relation between perceived risk and commitment and the customer less perceived risk in his interaction with a specific seller shows the high commitment to seller. There for these cases are suggested:

1. Try to create higher values and commitments for customers.

2. Respecting to customers negative opinions and analyze them to modify the seller-buyer relations.

3. Customer satisfaction Circular studying and assessment and purposive attempt to increase customer satisfaction.

\section{REFERENCES}

[1] Anderson, James C. James A. (1990), "A Model of Dis tributor Firm and Manufacturer Firm Working Partnerships," Journal of Marketing, 54, pp. 42-58.

[2] Arditto, L., Cambra-Fierro, J., Fuentes-Blasco, M., Jarabab Ana, O., Vázquez-Carrascob, R., (2020). How does customer perception of salespeople influence the relationship? A study in an emerging economy: Journal of Retailing and Consumer Services. 30, pp. 67-83.

[3] Baker, T., Simpson, P., Siguaw, J., (1999). The impact of suppliers'perceptions of reseller market orientation on key relationship constructs. J. Acad. Mark. Sci. 27, pp. 50-57.

[4] Bowen, J. T. Bowen \& Chen, S. L., (2001), "The Relationship Between Customer Loyalty and Customer Satisfaction". International Journal of Contemporary Hospitality Management, pp. 213-217.

[5] Chang, E., Tseng, Y., (2013). Research note: E-store image, perceived value and perceived risk. J. Bus. Res. 66, pp. 864-870.

[6] characteristics on customer retention in emerging online markets. $J$. Bus. Res. 92, pp. 25-35.

[7] Johnson, M. S., Sivadas, E., \& Garbarino, E. (2008). Customer satisfaction, perceived risk and affective commitment: an investigation of directions of influence. Journal of Services Marketing, 22(5), 353.362.

[8] Jaiswal, A.K., Niraj, R., Park, C.H., Agarwal, M.K., (2018). The effect of relationship and transactional consequences of customer trust in the salesperson. Eur. J. Market. 44, pp. 114-138.

[9] Echchakoui, S., (2016). Relationship between sales force reputation and customer behavior: role of experiential value added by sales force. J. Retail. Consum. Serv. 28, pp. 54-66.

[10] Fardhosseini, M. S., Soltaninejad, M., Karji, A., Ghorbani, Z. \& Ghanadiof, O. (2021). Qualitative Evaluation of 5S Application Considering the Experience of Electrical Construction Experts. American Journal of Applied Sciences, 18(1), pp. 51-60. https://doi.org/10.3844/ajassp.2021.51.60.

[11] Fornell, C., \& Larcker, D. F. (1981). Evaluating structural equation models with unobservable variables and measurement error. Journal of marketing research, 18(1), pp. 39-50.

[12] Ghanadiof, O. (2021). Customer Loyalty and Powerful Brand in Heavy Machinery Industry. European Journal of Business and Management Research, 6(3), pp. 195-199. https://doi.org/10.24018/ejbmr.2021.6.3.903.

[13] Grewal, D., Gotlieb, J., \& Marmorstein, H. (1994). The moderating effects of message framing and source credibility on the priceperceived risk relationship. Journal of consumer research, 21(1), pp. $145-153$.

[14] Guenzi, P., \& Georges, L. (2010). Interpersonal trust in commercial relationships: Antecedents and consequences of customer trust in the salesperson. European Journal of Marketing. Vol. 44 No. 1/2, pp. 114 138. https://doi.org/10.1108/03090561011008637.

[15] Lin, S.H. and Wu. H., (2012). Effects of ethical sales behavior considered through transaction cost theory: to whom is the customer loyalty. The journal of international management studies, 7(1), pp. 3140.

[16] Martínez, P., \& Del Bosque, I. R. (2013). CSR and customer loyalty: The roles of trust, customer identification with the company and satisfaction. International Journal of Hospitality Management, 35, pp. 89-99.

[17] Miremadi, A., Kenar Roudi, J., \& Ghanadiof, O. (2021). Evaluation on Role of Electronic Word of Mouth (EWOM) Ads in Customers' Emotions and Choices in E-Shops. International Journal of Industrial Marketing, 6(1). https://doi.org/10.5296/ijim.v6i1.

[18] Newell, S.J., Belonax, J.J., McCardle, M.W., Plank, R.E., (2011). The effect of personal relationship and consultative task behaviors on buyer perceptions of salesperson trust, expertise, and loyalty. J. Mark. Theory Pract. 19, pp. 307-316.

[19] Pelham, A.M. (2002), "An exploratory model and test of the influence of firm level consulting-oriented sales force programs on sales force performance", Journal of Personal Selling and Sales Management, Vol. 22 No. 2.

[20] Poon, P., Albaum, G., Yin, C., (2017). Exploring risks, advantages and interpersonal trust in buyer salesperson relationships in direct selling in a non-western country. Int. J. Retail Distrib. Manag. 45, pp.342-328.

[21] Sharma, A. (1990), "The Persuasive Effects of Salesperson Credibility: Conceptual and Empirical Examination, "Journal of Personal Selling \& Sales Management, 10, pp.71-80.

[22] Sharma, A. and Lambert, D. (1994), "How accurate are salesperson's perceptions of their customers?", Industrial Marketing Management, Vol. 21 No. 4, pp. 357-65.

[23] Wetzels, M., Odekerken-Schröder, G., \& Van Oppen, C. (2009). Using PLS path modeling for assessing hierarchical construct models: Guidelines and empirical illustration. MIS quarterly, pp. 177-195. 